\title{
FURTHER IMPROVED YOUNG INEQUALITIES FOR OPERATORS AND MATRICES
}

\author{
XiAnhe ZhaO, Le Li And Hongliang ZuO
}

\begin{abstract}
In this paper, we show some improvement of Young inequalities for operators and matrix versions for the Hilbert-Schmidt norm. On the basis of an operator equality, we prove intrinsic conclusion by means of a different method with others' researches. Besides, we present some reverse Young inequalities for positive operators.
\end{abstract}

Mathematics subject classification (2010): 47A30, 47A63.

Keywords and phrases: Jensen operator, reverse arithmetic-geometric means, Jensen's functional.

\section{REFERENCES}

[1] M. BAKHeRAD, M. S.Moslehian, Reverses and variations of Heinz inequality, Linear Multilinear Algebra., 63 (2015), 10, 1972-1980.

[2] S. Furuichi, On refined Young inequalities and reverse inequalities, J. Math. Inequ., 5 (2011), 1, 21-31.

[3] T. Furuta, J. Mićić Hot, J. Pečarić, Y. Seo, Mond-Pečarić Method in Oprator Inequalities, Element, Zagreb, 2005.

[4] F. HIAI, Matrix analysis: matrix monotone functions, matrix means, and majorization, Interdiscip. inf. Sci., 16 (2010), 139-248.

[5] F. Kittaneh, Y. Manasrah, Improved Young and Heinz inequalities for matrices, J. Math. Anal. Appl., 361 (2010), 1, 262-269.

[6] F. KitTANeh, Y. MANASRAh, Reverse Young and Heinz inequalities for matrices, Linear Multilinear Algebra., 59 (2011), 9, 1031-1037.

[7] F. Kittaneh, M. Krnić, N. Lovričević, J. PeČarić, Improved arithmetic-geometric and Heinz means inequalities for Hilbert space operators, Publ. Math. Debrecen., 80 (2012), 3-4, 465-478.

[8] M. KRniĆ, N. LOVRIČEviĆ, J. PEČARIĆ, Jensen's operator and applications to mean inequalities for operators in Hilbert space, Bull. Malays. Math. Sci. Soc., 35 (2012), 1, 1-14.

[9] F. Kubo, T. Ando, Means of positive operators, Math. Ann., 246 (1980), 3, 205-224.

[10] M. Tominaga, Specht's ratio in the Young inequality, Sci. Math. Japon., 55 (2002), 3, 583-588.

[11] J. G. ZHAO, J. L. Wu, Operator inequalities involvinf improved Young and its reverse inequalities, J. Math. Anal. Appl., 421 (2015), 1, 1779-1789.

[12] H. L. Zuo, M. FujII, J. I. FujII AND Y. SEO, Upper bound for spectra of Jensen operator and its application to reverse arithmetic-geometric means, Math. Inequal. Appl., 17 (2014), 2, 641-648. 